\title{
Transnational Environmental Law in Action: the European Union's Sustainable Biofuels Experiment
}

\author{
Jolene Lin*
}

NOTE: This is an Author's Original Manuscript of an article submitted for consideration in Environmental Politics [copyright Taylor \& Francis]; Environmental Politics is available online at http://www.tandfonline.com.

\section{Abstract}

Sustainable biofuels certification is an example of hybrid governance that locates authority, implementation and enforcement by state and non-state actors across borders. The emerging concept of "transnational environmental law" seeks to explore such forms of regulation beyond the state. This article argues that "transnational environmental law" provides a holistic perspective that breaks free of bounded notions of "law" and the "state" to capture the realities of social ordering (to address environmental challenges) at the periphery, instead of the traditional political centres of states and international organisations. However, this does not mean that the involvement or influence of states is diminished in any way. In the case of sustainable biofuels certification, states play an important role in creating incentives for other actors such as the market and civil society to play a role in global environmental regulation and orchestrating such multi-actor and multi-level regulatory arrangements.

\section{Introduction}

From the perspective of international environmental law (IEL), it would appear that the international community has done little, if anything at all, to address the environmental and socio-economic problems associated with industrial-scale biofuels production. ${ }^{1}$ The United Nations Environmental Programme (UNEP) has produced

\footnotetext{
*Associate Professor, Faculty of Law, The University of Hong Kong. Email: jolene@hku.hk. I am grateful to the editors of this special issue and my colleague, Dr. Marco Wan, for their helpful comments on an earlier draft of this article. The usual disclaimers apply.

${ }^{1}$ These problems have been well-explored in the literature; they include rampant deforestation and consequent biodiversity loss and ecological damage, "land grabs" and displacement of rural communities and indigenous peoples from their homes, and the controversial possibility that the production of biofuels releases more
} 
some excellent and thorough research. ${ }^{2}$ The World Bank and the Food and Agricultural Organization of the United Nations (FAO) have also addressed biofuels but within their institutional mandates of macro-economic policy and food security. ${ }^{3}$ As international organisations which are the classical arenas of international law-making, the UNEP, FAO and the World Bank have not advocated an international legal response in the form of a multilateral environmental treaty (MEA). Neither is an MEA the appropriate solution. Given the requirement of state consent and the need to create incentives for wide participation by states, MEAs typically feature rules and standards of the lowest common denominator cast in vague and legally non-binding language (i.e., that "States should endeavor..." instead of "States shall..."). ${ }^{4}$ Compliance has always been problematic because enforcement mechanisms in MEAs are typically weak or nonexistent. "Treaty congestion" is also a real concern. ${ }^{6}$ Neither customary international

greenhouse gases than the production of conventional transportation fuels like diesel and petroleum thereby fully running against one of the key policy rationales for promoting biofuels. See Towards Sustainable Production and Use of Resources: Assessing Biofuels, United Nations Environment Programme (UNEP), 2009 ["UN Report"]; Nuffield Council on Bioethics, Biofuels: Ethical issues (April 2011), available online: www.nuffieldbioethics.org (accessed on 9 April 2013); Jerry M. Melillo et al, Unintended Environmental Consequences of a Global Biofuels Program, MIT Joint Program on the Science and Policy of Global Change, Report No. 168 (January 2009); Claude Mandil and Adnan Shihab-Eldin, Assessment of Biofuels Potential and Limitations (International Energy Forum, February 2010); A. Ajanovic, "Biofuels versus food production: Does biofuels production increase food prices?" (2011) 36 Energy 2070-2076. Searchinger, T., Heimlich, R., Houghton, R. A., Dong, F., Elobeid, A., Fabiosa, J., Tokgoz, S., Hayes, D. and Yu, T.-H., "Use Of US Croplands For Biofuels Increases Greenhouse Gases Through Emissions From Land Use Change" (2008) 319 Science 1238-1240.

${ }^{2}$ UN Report; The UNEP was one of the three organisers of the following research project, Franke, Bernd; Reinhardt, Guido; Malavelle, Jérôme; Faaij, André; Fritsche, Uwe, Global Assessments and Guidelines for Sustainable Liquid Biofuels, (A GEF Targeted Research Project. Heidelberg/Paris/Utrecht/Darmstadt, 29 February 2012), online:

http://www.unep.org/bioenergy/Portals/48107/doc/activities/GEF\%20Liquid\%20Biofuel\%20Project.pdf (accessed on 9 April 2013).

${ }^{3}$ See M. Kojima et al, Considering Trade Policies for Liquid Biofuels, World Bank, Renewable Energy Special Report 004/07, May 2007, available online:

http://siteresources.worldbank.org/INTOGMC/Resources/Considering trade policies for liquid biofuels.pdf (accessed on 1 April 2013); Aziz Elbehri, Anna Segerstedt and Pascal Liu, Biofuels and the sustainability challenge: A global assessment of sustainability issues, trends and policies for biofuels and related feedstocks (FAO, 2013), online: http://www.fao.org/docrep/017/i3126e/i3126e.pdf (accessed on 1 April 2013).

${ }^{4}$ B. Simma, "From Bilateralism to Community Interest", (1994) 250 Recueil des cours 221; D.M. Johnston, Consent and Commitment in the World Community: The Classification and Analysis of International Instruments (Transnational Publishing, 1997), pages 62-63; Scott Barrett, Environment and Statecraft: Strategies of Environmental Treaty-Making (Oxford, New York: Oxford University Press, 2003).

${ }^{5}$ For an alternative view that emphasises facilitation of compliance and legitimacy as an important factor in increasing a treaty regime's "compliance pull", see Jutta Brunnée, "Enforcement Mechanisms in International Law and International Environmental Law" in in Ulrich Beyerlin et al, eds., Ensuring Compliance with Multilateral Environmental Agreements: A Dialogue Between Practitioners and Academia (Martinus Nijhoff, 2005). 
law nor the general principles of law offers much guidance too. In any event, they will only offer guidance in a meaningful way through litigation which is itself a poor response to global environmental challenges. ${ }^{7}$ In short, by focusing on classical IEL which comprises of treaties, general principles and customary international law, it would appear that the law offers anaemic responses to the environmental destruction and social injustice engendered by industrial biofuels production.

However, the picture is markedly different the moment we expand our visual field beyond the state (including intergovernmental organisations which are created by states) and the corpus of IEL created by states. This expansion can take place on two levels. On one level, we could expand our visual field in disciplinary terms: in addition to the legal framework, there is a rapidly growing body of political science literature that seeks to examine the causes and consequences of regulation by non-state actors including industry associations and networks of technical experts. Cutler, Haufler and Porter's pioneering work on private authority used a series of in-depth studies of particular cases of international private regulation to shed light on the theoretical and empirical questions: Why would firms cooperate to establish frameworks to govern their conduct, for example, regarding labour conditions and environmental safety? How do such forms of private regulation operate and how do they gain authority $?^{8}$ Subsequent works by Hall and Biersteker, Buthe, Green and Bartley, to name a few, shed further light on these questions. ${ }^{9}$ Additionally, scholars including Strange, Ruggie and Sassen

\footnotetext{
${ }^{6}$ Edith Brown Weiss, "International Environmental Law: Contemporary Issues and the Emergence of a New World Order" (1993) 81 Georgetown Law Journal 675.

${ }^{7}$ For resounding criticism of the International Court of Justice's lack of aptitude in adjudicating environmental disputes, see the joint dissenting opinion of Judges Al-Khasawneh and Simma in Pulp Mills on the River Uruguay (Argentina v. Uruguay), online: http://www.icj-cij.org/docket/files/135/15879.pdf (last visited on 1 April 2013); for discussion of environmental litigation in international tribunals, see Tim Stephens, International Courts and Environmental Protection (Cambridge University Press, 2009).

${ }^{8}$ A. C. Cutler, V. Haufler and T. Porter, Private authority and international affairs (Albany, NY: State University of New York Press, 1999).

${ }^{9}$ R. B. Hall and T. J. Biersteker, The emergence of private authority in global governance (Cambridge: Cambridge University Press, 2002); T. Büthe, "Governance through private authority? Non-state actors in world politics" (2004) 58(1) Journal of International Affairs 281-290; T. Buthe, "Private Regulation in the Global Economy: A (P)Review" (2010) 12(3) Business and Politics, Article 2; J.F. Green, "Private authority in global environmental politics: Delegation to non-state actors in multilateral environmental treaties" Presented at the American Political Science Association (2008), online: http://iea.uoregon.edu/pages/publications/2008-Green Delegation_APSA.pdf (accessed on 9 June 2013); T. Bartley, "Transnational private regulation in practice: The limits of forest and labor standards certification in Indonesia" (2010)12(3) Business and Politics.
} 
have explored (and hold differing views of) the effect of the rise of private regulation on public regulatory authority. ${ }^{10}$ Whytock has questioned if private regulation can operate effectively in the absence of stable and reliable domestic legal systems given the limitations of reputational enforcement mechanisms. ${ }^{11}$ On the other end of the spectrum is Strange's famous proclamation that "[w]here states were once the masters of markets, now it is the markets which, on many crucial issues, are the masters over the governments of states. And the declining authority of states is reflected in a growing diffusion of authority to other institutions and associations..."12

On another level, the expansion of the visual field has been marked by the move from IEL to transnational environmental law (TEL). This article shall focus on what is at stake in this move. The underlying premise is that a single-minded focus on the traditional preoccupations of IEL discourse such as the emergence of customary international law and the case-law of the international tribunals creates a blind spot on the area between the "domestic" and the "international". This single-minded focus that IEL scholars have harks back to adherence to a conception of law that is invariably bound to state sovereignty. If one is open to making the conceptual move away from such formalistic notions of law, one "opens up" the necessary space to consider novel forms of governing. Many IEL scholars have made such a conceptual move to expand their visual field by drawing on the insights and methodologies of disciplines ranging from international relations to new institutional economics. ${ }^{13}$ This article argues that this has led to the emerging concept of TEL, whether or not scholars allude to it intuitively

\footnotetext{
${ }^{10} \mathrm{~S}$. Strange, The retreat of the state: The diffusion of power in the world economy (Cambridge: Cambridge University Press, 1996); J. G. Ruggie, "Reconstituting the global public domain-issues, actors, and practices" (2004) 10(4) European Journal of International Relations 499-531; S. Sassen, Losing control?: Sovereignty in an age of globalization (New York: Columbia University Press, 1996).

${ }^{11}$ C.A. Whytock, "Private-Public Interaction in Global Governance: The Case of Transnational Commercial Arbitration" (2010) 12(3) Business and Politics, Article 10, pages 17-22.

${ }^{12} \mathrm{~S}$. Strange, The retreat of the state: The diffusion of power in the world economy (Cambridge: Cambridge University Press, 1996), page 4.

${ }^{13}$ Economists were amongst the first scholars to theorise the transnational dimensions of trade and culture in the world economy that have evolved throughout history; for example, Karl Marx and Friedrich Engels (1848) Das kommunistische Manifest (Berlin, Dietz). This body of work built on and complemented work by political scientists like Jonah D. Levy and Samuel P. Huntington on the influence of globalisation on national and regional political economies. It soon became clear, as this body of research grew, that it was necessary or useful to develop a concept that could capture the "space between the 'international' and the 'national'" (Gralf-Peter Calliess and Peer Zumbansen, Rough Consensus and Running Code: A Theory of Transnational Private Law (Oxford and Portland, Oregon: Hart Publishing, 2010, page 13).
} 
(/implicitly) or consciously (/explicitly). ${ }^{14}$ At the same time, TEL can also be seen to be an extended application of "transnational law" to the context of environmental regulation. ${ }^{15}$

With an expanded visual field, it could be observed, for example, that normative rules are being made and implemented by corporations and environmental nongovernmental organisations in forums that have impact across national borders. ${ }^{16} \mathrm{We}$ would also observe that State X's environmental law can have profound legal and regulatory impacts on State $Y$ and may even be more effective in improving the latter's environmental record in its biofuels production activities than an MEA. The advocacy of an "expanded visual field" approach is not new. In fact, a vast majority of IEL scholarship, particularly that of American scholars, adopts an inter-disciplinary approach towards IEL. There is a shared awareness that the state-centric doctrines of IEL are illsuited to theorizing many modern developments such as the "green economy". ${ }^{17} \mathrm{~A}$ retort could be that such developments fall outside the purview of the "law" so it is not a question of the limitations of IEL but that IEL scholars are dealing with "non-law". However, this would be a simplistic retort. Scholars theorising about domestic law in its wider socio-economic and political context (broadly known as sociology of law

\footnotetext{
${ }^{14}$ Examples of the former include Hari M. Osofsky, "Climate Change Litigation as Pluralist Legal Dialogue?" (2007) 26A Stanford Environmental Law Journal \& 43A Stanford Journal of International Law 181 (joint issue); Hari M. Osofsky, "Climate Change and Dispute Resolution Processes" in International Law in the Era of Climate Change (Rosemary Rayfuse \& Shirley V. Scott, eds., Edward Elgar, 2012); Joanne Scott, "From Brussels with Love: The Transatlantic Travels of European Law and the Chemistry of Regulatory Attraction" (2009) 57(4) The American Journal of Comparative Law 897-942. Examples of the latter include David M. Ong, "From 'International' to 'Transnational' Environmental Law? A Legal Assessment of the Contribution of the 'Equator Principles' to International Environmental Law" (2010) 79 Nordic Journal of International Law 35-74; the articles in the inaugural issue of Transnational Environmental Law, published in April 2012, online: http://journals.cambridge.org/action/displayJournal?jid=TEL (accessed on 1 April 2013).

${ }^{15}$ Julia Black defines "regulation" as "the sustained and focused attempt to alter the behaviour of others according to defined standards or purposes with the intention of producing a broadly identified outcome or outcomes, and which may involve mechanisms of standard-setting, information-gathering and behaviour-modification"; Julia Black, "Enrolling Actors in Regulatory Systems: Examples from UK Financial Services Regulation" (2003) Public Law at 63,65 .

${ }^{16}$ Margaret E. Keck and Kathryn Sikkink, Activists beyond Borders: Advocacy Networks in International Politics (Cornell University Press, 1998).

${ }^{17}$ E. Morgera \& A. Savaresi, “A Conceptual and Legal Perspective on the Green Economy” (2013) 22 Review of European, Comparative \& International Environmental Law 14-28, doi: 10.1111/reel.12016; for a highly compelling critique of the notion of "sustainable development" in IEL, see Donald K. Anton, "The 2012 United Nations Conference on Sustainable Development and the Future of International Environmental Protection" (2012) 7(1) Consilience: The Journal of Sustainable Development 64-72.
} 
scholarship) faced a similar battle more than two decades ago. Although the sociological study of law coexists uneasily with the established discipline of law, the latter has changed in important respects to accommodate the perspectives of the former. ${ }^{18}$ "Law in context" is now a widely accepted approach towards legal analysis; reflexive law and "new governance" recognise that "law" today goes beyond rules backed by sanctions and punishment and the state does not maintain a monopoly over rule-making but nonetheless retains a significant role in the modern regulatory state. ${ }^{19}$

Similarly, the boundary between "law" and "non-law" in IEL is a contested one. There is a complex of norms, actors and processes that have developed at multiple "sites" and "levels" beyond the simple dichotomy of the Westphalian duo of municipal domestic law and inter-state law. To an extent, this "law" versus "non-law" contention reflects a broader, enduring debate over normative pluralism and the concept of law in legal theory. While the concept of "law" remains open to contestation, it is essential to have a "working definition" to clarify the parameters of discussion in this article. The definition has to be sufficiently open-ended to guide inquiry, and not close off inquiry before it begins by conclusively specifying the nature of the object of study (the makings of a tautological debate!). ${ }^{20}$ As such, in this article, "legal norms" refer to norms that lay out behavioural prescriptions issued by an authoritative source in written form; they can be formally binding or not; and they can be backed by dispute settlement and enforcement systems or not. ${ }^{21}$ Admittedly, this definition is broad enough to include village custom and religious rules; what distinguishes legal norms is that the behavioural prescriptions are ultimately intended to achieve policy goals of the state. The state indirectly or directly taps on different networks, pathways and sites of normative influence to regulate society. In this manner, law takes on a far wider, more diffused, more complex role in the modern nation state and global society.

\footnotetext{
${ }^{18}$ Roger Cotterrell, The Sociology of Law: An Introduction (United Kingdom: Butterworths, 1992), page 8.

${ }^{19}$ See discussion in Part III below.

${ }^{20}$ This takes a leaf from Cotterrell's distinction between a definition of law and a model of law; Roger Cotterrell, The Sociology of Law: An Introduction (United Kingdom: Butterworths, 1992), page 38.

${ }^{21}$ G. Shaffer, "Transnational Legal Process and State Change" (2012) 37(2) Law \& Social Inquiry 229-264, at page 234. [Transnational Legal Process and State Change]
} 
This article examines a particular biofuels regulatory regime through the lens of TEL. The regulatory regime that the European Union (EU) has set up to govern the production of biofuels from "the field to the tank" relies heavily on a novel combination of regulatory approaches. These approaches include delegation of regulatory authority to non-state market-based certification schemes and audit firms, use of market access to ratchet up environmental standards in exporting countries (alternatively, attaching environmental condition precedents to biofuel exports into the European market), and legal unilateralism. Traditional IEL discourse will dismiss such regulatory innovation as irrelevant despite the clear implications that the EU scheme will have for the international system of managing natural resources. Using the concepts of TEL, however, unlocks the potential to analyse the implications of emerging forms of nontraditional governing in the international arena.

Part II of this article provides a fuller elaboration of TEL. If we are "still in search of transnational law, including the very concept of 'transnational law', and not yet at the stage of fattening it out (as concept)", the same is true of TEL. ${ }^{22}$ This article is a humble attempt to outline the contours of the emerging concept of TEL. Part III analyses the EU's sustainable biofuels regulatory regime as a case study of TEL in practice and advances two arguments. First, the TEL perspective provides a more nuanced role of the state in global environmental governance than that provided by IEL. The case study of the EU sustainable biofuels regime shows that the state plays an important role of orchestrating multi-actor initiatives and also creates TEL through unilateral action (as opposed to multilateral negotiations). Secondly, TEL in the EU biofuels context raises two broad questions concerning legitimacy. The first question is whether it is legitimate for economically powerful state actors to use trade-based measures to unilaterally direct international policy. The second question is whether there are any satisfactory responses to the claim that private regulation (that is, by certification schemes and auditors) is non-democratic and therefore illegitimate. This article argues that unilateralism can be legitimate if due process and non-discrimination norms laid down in international law are adhered to. As for the second claim, this article takes the view that

\footnotetext{
${ }^{22}$ Craig Scott, "'Transnational Law' as Proto-Concept: Three Conceptions" (2009) 10(7) German Law Journal 859876, page 864. [Craig Scott]
} 
private regulation is not more undemocratic than international law. The attempts by certification schemes to be, for example, more inclusive of a wide array of actors from developed and developing countries are pragmatic efforts to build legitimacy when there is no agreed-upon notion of "democracy" in the transnational arena. Part IV concludes that broadening our horizons beyond IEL, TEL provides a small but useful "vocabulary" for scholars to highlight and theorise alternative regulatory options and innovations such as public-private partnerships, market-based certification schemes, the use of market access to promote environmental goals, and so on. The use of the term "vocabulary" is a deliberate choice as there is, as yet, no discourse or well-developed methodology associated with TEL. It is not an established concept. However, TEL appears to be a promising avenue for breaking free of the shackles of state-centred ideas of law to capture the realities of social ordering today and there is potential for developing it as a methodological approach for environmental law scholars.

\section{Part II: What is Transnational Environmental Law?}

Starting with the proposition that TEL has its origins in the 'transnational law' literature and is emerging from efforts by scholars to borrow and apply 'transnational law' to the field of environmental studies, the exploration of what TEL is begins here with some preliminary observations of how "transnational law" has been conceptualised. From the outset, it must be noted that there is a vast (and expanding) body of transnational law literature as scholars from different fields ranging from commercial law to administrative law have sought to engage with the concept of transnational law as part of their observations of the impact of globalisation on discrete areas of law. ${ }^{23}$ These preliminary observations are therefore introductory in nature, barely skimming the

\footnotetext{
${ }^{23}$ For a small sample, see, Roy Goode, Herbert Kronke, Ewan McKendrick, Transnational Commercial Law (Oxford University Press, 2007); Benedict Kingsbury et al, "Global Governance as Administration - National and Transnational Approaches to Global Administrative Law" (2005) 68 (3 \& 4) Law and Contemporary Problems 1-13 and the articles introduced therein; Neil Boister, "Transnational Criminal Law?" (2003) 14 European Journal of International Law $953-976$. By globalisation, I mean all the complex processes that have increased interaction and interdependence across state and cultural barriers in respect of communications, public health, ecology, finance and so on; William Twining, Globalisation and Legal Theory (Northwestern University Press, 2001), page 7-8.
} 
surface of the debates in the literature; the aim here is merely to capture the salient aspects of transnational law which shape the conceptual contours of TEL.

As a starting point, there is no reason why one ought not to begin with Jessup's oft-quoted passage from his Storrs Lectures on Jurisprudence just over fifty years ago at Yale Law School as many scholars have done in trying to get a grip on the use of the term "transnational law".

I shall use, instead of "international law", the term "transnational law" to include all law which regulates actions or events that transcend national frontiers. Both public and private international law are included, as are other rules which do not wholly fit into such standard categories.

Philip Jessup, Transnational Law 136 (1956)

It is clear that Jessup's conception of "transnational law" was a broad category that includes public international law, private international law and other rules that governs actions or events (i.e., physical occurrences) that have elements in more than one jurisdiction. ${ }^{24}$ An example is a chemical spill in a river that runs between two states and therefore causing pollution in more than one jurisdiction. In Scott's illuminating discussion of transnational law (which he views to be at such an early stage of emergence that he calls it a "proto-concept"), he presents three different but not necessarily mutually exclusive conceptions that are extrapolated from Jessup's formulation. First, "transnationalized legal traditionalism" focuses on the first sentence of Jessup's premise. The "law" as we know it, that must deal with various transnational phenomena, comprises of public international law and domestic law. "On this account, there is not- and no need for - something distinct called "transnational law" for such 'law' would invariably be given shape and be

\footnotetext{
${ }^{24}$ Public international law came into existence with the rise of sovereign states in the seventeenth century. It is commonly viewed as the body of law that governs relations between states (for example, the law governing diplomatic relations) and that which arises from joint efforts by states to address issues of common concern (for example, biological diversity loss, money-laundering, and human trafficking). Private international law is the body of rules that apply to resolve situations whereby more than one state asserts jurisdiction over a transaction or event. It is the body of law that can be resorted to in the event of "conflict of laws" between states (private international law is also known as "conflict of laws").
} 
permitted to exist only as the combined functioning of public international law and domestic legal systems, and their mutually regulated interactions". ${ }^{25}$

The second approach is dubbed "transnationalized legal decisionism". As the name suggests, this approach conceives of transnational law as the outcome of legal decision-making processes that have employed both domestic and international law to provide a body of potentially applicable rules to resolve a transnational issue, problem or dispute. ${ }^{26}$ This approach can be seen in the way constitutional courts engage in dialogue, whether physically through meetings of judges to exchange insights or metaphorically through references in judgments to relevant case law in other jurisdictions, and which has been theorised within what some would call the transnational legal process school. ${ }^{27}$

Scott's third conception is dubbed "transnational socio-legal pluralism" and captures an approach that has generated much literature. It is also within this conception (and "transnationalized legal decisionism") that TEL appears to fit. This approach sees transnational law as being somewhat autonomous of domestic law and international law (including private international law). It is imagined to occupy its own normative sphere, the nature of which is "constructed" (by interacting legal, policy and moral discourses) instead of being "found" or "given". The "other rules", referred to in the final line of Jessup's framing, are seen by adherents of the "transnational socio-legal pluralism" approach as the truly transnational rules. ${ }^{28}$ One of the earliest works to theorise about the emergence of these "other rules" that do not fall neatly within the established categories (of public international law, private international law and domestic law) was Teubner's stage-setting chapter in Global Law without a State. The title of the chapter, “Global Bukowina': Legal Pluralism in

\footnotetext{
${ }^{25}$ Craig Scott, page 869.

${ }^{26}$ Craig Scott, page 871.

${ }^{27}$ See, for example, Anne-Marie Slaughter, “Judicial Globalization" (2000) 40 Virginia Journal of International Law 1103; Jörg Philipp Terhechte, "Judicial Ethics for a Global Judiciary - How Judicial Networks Create their own Codes of Conduct" (2009) 10(4) German Law Journal 501-514; Curtis A. Bradley, International Law in the U.S. Legal System (Oxford University Press, 2013); David S. Law \& Wen-Chen Chang, "The Limits of Global Judicial Dialogue" (2011) Washington Law Review 523-577; M. Kirby, "Transnational Judicial Dialogue, Internationalisation of Law and Australian Judges" (2008) 9(1) Melbourne Journal of International Law.

${ }^{28}$ Craig Scott, page 873.
} 
the World Society" pays homage to Eugen Ehrlich's concept of the living law. According to Ehrlich, law was not to be found in the political centres of power but in the every-day customs, habits and practices which the common folk adhered to. ${ }^{29}$ Transposing Ehrlich's insight that "[t]he center of gravity of legal development therefore from time immemorial has not lain in the activity of the state, but in society itself, and must be sought there at the present time" to the plane of the contemporary global economy, Teubner argued that "global law will grow mainly from the social peripheries, not from the political centres of nation-states and international institutions". ${ }^{30}$ Using lex mercatoria, the law of economic transactions that has developed to mediate between enterprises with little or no involvement of state authorities since medieval times, as the quintessential example of "global law without the state", Teubner argued that lex mercatoria "breaks a double taboo about the necessary connections between law and state". ${ }^{31}$ First, that merely private orders and actors can produce valid law without state authorisation. Secondly, that such "law" as produced by lex mercatoria claims to be valid across national borders. Given lex mercatoria's break with tradition, it cannot be theorised using positivist theories of law. ${ }^{32}$ Resort must therefore be made, Teubner argues, to theories of legal pluralism which treat political, legal and social production of norms on an equal footing. ${ }^{33}$ According to legal pluralist theories, legally non-binding norms that are generated by, for example, institutions formed by firms and non-governmental

\footnotetext{
${ }^{29}$ For discussion of Ehrlich's "living law" concept, see David Nelken, "Eugen Ehrlich, Living Law and Plural Legalities" (2008) 9(2) Theoretical Inquiries in Law 443-471.

${ }^{30}$ The first quotation in the sentence is from Ehrlich, 1936: 390, reproduced on the same page where the second quotation from Teubner can be found; G. Teubner, "'Global Bukowina': Legal Pluralism in the World Society" in G. Teubner (ed.) Global Law Without a State (Dartmouth Publishing Company, 1997), page 7. [Teubner]

${ }^{31}$ Teubner, page 11. For an excellent introduction to the historical development of lex mercatoria, see Alec Stone Sweet, "The new Lex Mercatoria and Transnational Governance" (2006) Vol. 13(5) Journal of European Public Policy 627-646.

${ }^{32}$ Simply, the questions for positivists applying Kelsen or Hart would be: "Where is the global grundnorm? Where is the global 'rule of recognition'"? (Teubner, page 11) However, this has not prevented scholars from attempting to reconcile transnationalism with positivist theories of law. See, for example, D. Von Daniels, The Concept of Law from a Transnational Perspective (Ashgate Publishing, 2010); also see Cotterrell's critique in "What is Transnational Law?" (2012) 37(2) Law \& Social Inquiry 500-524.

${ }^{33}$ For a convincing critique of the lack of continuity between "global legal pluralism" and the older anthropological and socio-legal accounts of legal pluralism, see William Twining, "Normative and Legal Pluralism: A Global Perspective" (2010) Duke Journal of International and Comparative Law 473-517.
} 
organisations may be viewed as "law" for participating firms. ${ }^{34}$ Distinctions between "transnational law" and "global law" have been drawn and Teubner's work has come to be regarded as closer to the latter than the former, but Teubner continues to influence the way scholars think and theorise about transnational law.

Shaffer draws the following distinction between global law and transnational law: Global law refers to universal legal norms that are created and diffused by states and private actors. These universal norms need not be produced as a result of agreement by states, but claim to be universal in application or have universal validity. ${ }^{35}$ Transnational law, on the other hand, does not make such claims of universality. Transnational law can include traditional international law (both public and private) "but also encompass legal rules and norms that have effects across borders without any binding agreement among states, whether they are created by international organizations, intergovernmental networks, or private actors, and whether they are of a hard or soft law nature". ${ }^{36}$

Shaffer further distinguishes between two conceptual facets of transnational law. The first, "Transnational Law Applying to Transnational Situations", refer to law that targets transnational events, activities and situations that involve more than one jurisdiction. Jessup's formulation and Craig's three conceptions of transnational law are examples of the use of the term "transnational law" in this first sense. Shaffer's second conceptualisation captures the notion of the creation and diffusion of norms by casting the spotlight on "...the transnational production of legal norms and institutional forms and their migration across borders, regardless of whether they address transnational activities or purely national ones". ${ }^{37}$ This second conception

\footnotetext{
${ }^{34}$ See Errol Meidinger, "Forest Certification as Environmental Law-Making by Global Civil Society" in Errol Meidinger et al (eds.), Social and Political Dimensions of Forest Certification (Remagen-Oberwinter, Germany: Forstbuch. 2002), page 299-300.

${ }^{35}$ As Perez puts it, "[t]he globality of these systems stems from their (parallel) claim for universal validity, and from the cosmopolitan nature of their thematic horizon (which means that their normative effort is directed primarily at global issues"; see Oran Perez, "Normative Creativity and Global Legal Pluralism: Reflections on the Democratic Critique of Transnational Law" (2003) 10(2) Indiana Journal of Global Legal Studies 25-64, page 26.

${ }^{36}$ Transnational Legal Process and State Change, at page 233.

${ }^{37}$ Ibid. at page 234 .
} 
also emphasises the role of transnational actors "... be they institutions or networks of public or private actors...in constructing and diffusing legal norms". ${ }^{38}$

We now shift the focus to TEL with resort to Shaffer's conceptualisations. The application of Shaffer's first conception to the environmental sphere is not controversial: transnationalism flows from the nature of environmental problems as usually being cross-border. Environmental disputes often arise from trans-boundary harm such as plumes of air pollutants from State $\mathrm{X}$ to State $\mathrm{Y}$, or a chemical spill that originates in a river within State $\mathrm{X}$ but causes ecological devastation further downstream in the river basin shared by a number of states. Such trans-frontier environmental disputes are the raison d'être of early IEL.

It is Shaffer's second conception that yields more interesting insights for sketching the contours of TEL. At the risk of repetition, we can say at this juncture that TEL comprises of (1) law that applies to trans-boundary situations whereby the legal norms can derive from domestic legal systems, public international law, or private ordering such as mediated settlements between a polluter and the affected communities; (2) the study of how legal norms are created and diffused by institutions and networks of actors which exercise influence beyond a jurisdiction (and may be public, private or hybrid in nature) to induce improved environmental performance in target states, industries and communities with close connections with the environmental resource at stake (for example, indigenous peoples and forests); (3) the study of the outcomes of such patterns of norm creation and diffusion and (4) the study of normative concerns that arise from transnational legal structures such as their legitimacy. ${ }^{39}$ It should also be noted that norms do not need to be "environmental" in the sense that they are created primarily in response to environmental regulatory needs in order to be deemed relevant for study from a TEL perspective. Resort to "other" bodies of law such as human rights law and international trade law to achieve environmental objectives such as protecting an

\footnotetext{
${ }^{38} \mathrm{Ibid}$. at page 235 .

${ }^{39}$ See, for example, Neil Craik, "Deliberation and Legitimacy in Transnational Environmental Governance", IIL Working Paper 2006/10 (Global Administrative Law Series); articles in "Special Issue: Law, expertise and legitimacy in transnational economic governance" (2010) 8(1) Socio Economic Review; David Szablowski, Transnational Law and Local Struggles: Mining Communities and the World Bank (Hart Publishing, 2007).
} 
endangered species of sea turtle is usually a strategic decision. That in itself justifies attention because valid questions arise, for example, whether the World Trade Organisation (WTO) is the appropriate forum for pursuing environmental goals. ${ }^{40}$

\section{PART III: The EU's Quest for Sustainable Biofuels}

In this Part III, we will examine the biofuels governance framework that has been put in place in the EU as an example of TEL in practice. At this juncture, some background information to provide a contextual understanding of this "sustainable biofuels" regime will be useful.

Biofuels have been around for more than a century. ${ }^{41}$ In the 2000s, a conflux of factors created the biggest window of opportunity for the commercial development of biofuels. These three factors are climate change, energy security and rural development. Touted as a "triple-win" silver bullet that could help lower greenhouse gas emissions, enhance energy security and promote rural development, governments of developed and developing countries alike jumped on the biofuels bandwagon. ${ }^{42}$ Every biofuels programme to date has been supported by extensive governmental intervention in the form of research grants, laws and regulations, subsidies and import tariffs because biofuels have historically been more expensive to produce compared to petroleum fuels. $^{43}$

\footnotetext{
${ }^{40}$ There is a wealth of scholarship on this issue. For a small sampling, see Laurence Boisson de Chazournes, "Unilateralism and Environmental Protection: Issues of Perception and Reality of Issues" (2000) 11(2) European Journal of International Law 315-338; R.W. Parker, "The Use and Abuse of Trade Leverage to Protect the Global Commons: What We Can Learn from the Tuna-Dolphin Conflict" (1999) 12 Georgetown International Environmental Law Review 1; Jeffrey L. Dunoff, "Institutional Misfits: The GATT, The ICJ \& Trade-Environment Disputes" (1994) 15 Michigan Journal of International Law 1043; David Vogel, "The Environment and International Trade" (2000) 12(1) Journal of Policy History 72-100; Carmen G. Gonzalez, "Beyond Eco-Imperialism: An Environmental Justice Critique of Free Trade"(2001) 78(4) Denver University Law Review 979-1016.

${ }^{41}$ At the World Fair held in Paris in 1900, the demonstration model of Rudolf Diesel's invention, the diesel engine, operated on peanut oil.

${ }^{42}$ It should be noted, however, that political and socio-economic factors dictate the relative weight that States attach to climate change mitigation, energy security and rural development and that this "trio of benefits" is a glib sound bite which glosses over the policy contradictions that can arise from trying to achieve all three objectives simultaneously. See discussion in The Royal Society, Sustainable Biofuels: Prospects and Challenges (Policy document 01/08, January 2008), online: www.royalsociety.org.

${ }^{43}$ Antonio M. Bento, "Biofuels: Economic and Public Policy Considerations" in R.W. Howarth and S. Bringezu (eds), Biofuels: Environmental Consequences and Interactions with Changing Land Use, Proceedings of the Scientific Committee on Problems of the Environment (SCOPE) International Biofuels Project Rapid Assessment, 22-25
} 
In the EU, the year 2003 witnessed the launch of more aggressive policies to encourage the development of the biofuels industry. ${ }^{44}$ The focus during this period was on stimulating biofuels demand and supply, and little attention was paid to the environmental and socio-economic effects. Between 2005 and 2008, biofuels incentive programmes in the United States, the EU and some two dozen other countries contributed to world food markets experiencing the largest price shocks in thirty years. ${ }^{45}$

The European Commission soon came under mounting pressure from scientists, environmental and human rights non-governmental organisations, and some member states (e.g. Germany, Italy, France and the United Kingdom) to address the environmental and food security dimensions of biofuels. ${ }^{46}$ Subsequently, to allay these concerns about the environmental harm that biofuels production could cause in developing countries, the 2009 Renewable Energy Directive (RED) included the "sustainability criteria" for biofuels. ${ }^{47}$ Briefly, these criteria specify that biofuels must provide at least $35 \%$ greenhouse gas emission savings compared to fossil fuels and must not come from crops cultivated on land with a high biodiversity value or on former peat land. ${ }^{48}$ While a type of biofuel can be imported into the EU even if it does not meet the sustainability standards, compliance is required in order for the biofuel in question to count towards attainment of EU or national renewable energy obligations or to be eligible for financial support. ${ }^{49}$ In this regard, the sustainability criteria are not legally mandatory requirements but exporters that fail to meet these requirements will encounter restricted access to the EU market.

September 2008, Gummersbach, Germany, online: http://cip.cornell.edu/scope/1245782000 (accessed on 1 August 2012); Michael B. Charles, Rachel Ryan, Neal Ryan, and Richard Oloruntoba, "Public policy and biofuels: The way forward?" (2007) 35 Energy Policy 5737-5746, page 5741; OECD, Trade and Agriculture Directorate, Committee for Agriculture, Working Party on Agricultural Policies and Markets, "A Review of Policy Measures Supporting Production and Use of Bioenergy", Document Number: TAD/CA/APM/WP(2007)24/FINAL (July 2008), available online: http://www.oecd.org/dataoecd/37/43/41037609.pdf (accessed on 23 March 2013).

${ }^{44} \mathrm{C}$. Charles et al, Biofuels- At What Cost? Government support for ethanol and biodiesel in the European Union (Global Subsidies Initiative, 2013), online: http://www.iisd.org/gsi/biofuel-subsidies/biofuels-what-cost, page 17.

${ }^{45}$ Robert Bailis \& Jennifer Baka, "Constructing Sustainable Biofuels: Governance of the Emerging Biofuel Economy", (2011) 101(4) Annals of the Association of American Geographers 827-838, page 828. [Bailis \& Baka] ${ }^{46}$ A. Mol, "Environmental authorities and biofuel controversies'", (2010) 19(1) Environmental Politics 61- 7, page 72.

${ }^{47}$ Directive 2009/28/EC on the promotion of energy from renewable sources OJ [2009] L145/16.

${ }^{48} \mathrm{Ibid}$, Article 17. For discussion of the complexities and contested meanings of "sustainability" and how this carries through to biofuels governance, see Bailis \& Baka.

${ }^{49}$ Directive 2009/28, Article 17(1). 
The interesting features of this attempt to ensure that biofuels consumed within the EU meet some requirements, albeit limited, concerning ecological sustainability, lie in the compliance framework and the underlying policy commitment to "greening market access". Using the second prong of the above-mentioned scope of TEL as a guide, our attention is drawn to how the sustainability criteria is found in an EU directive, implemented by the European Commission through a multi-layered network of public, private or hybrid institutions and actors which diffuse these norms, and induce regulatory action (that will lead to compliance with the sustainability criteria) by actors located outside the EU.

\section{$\underline{\text { The Compliance Framework }}$}

The Commission does not directly ensure that a biofuel product satisfies the sustainability criteria. ${ }^{50}$ The task of "certifying" biofuels as being compliant is delegated to certification schemes that have been developed by business associations, non-profit organisations and governments usually working in partnership. These initiatives are usually labelled "roundtables" or "stewardship councils" to signal their multi-stakeholder nature. $^{51}$

The Commission "benchmarks" these certification schemes against the RED sustainability criteria to determine the extent to which a certification scheme addresses the sustainability criteria and the robustness of its verification system. Subsequently, a producer or importer (in the Commission's language, an "economic operator") can rely on certification by a recognised scheme to demonstrate compliance with the RED sustainability criteria. To demonstrate independence and transparency, a certification scheme, in turn, relies on auditing by third-party entities such as accreditation bodies before it affixes its "approved" seal on the biofuel product. As these accreditation bodies

\footnotetext{
${ }^{50}$ For detailed discussion, see J. Lin, “Governing Biofuels: A Principal-Agent Analysis of the European Union Biofuels Certification Regime and the Clean Development Mechanism" (2012) 24 (1) Journal of Environmental Law 43-73, pages 53-59.

${ }^{51}$ For discussion, see Stefano Ponte, "Roundtabling' Sustainability: Lessons from the biofuel industry" (Conference manuscript, on file with author), pages 1-3.
} 
are separate entities from those involved in devising the rules and implementing the certification scheme, they are cast as independent arbiters of the verification process and therefore fit to "regulate the regulators". 52

The responsibility of monitoring and verification is therefore divided amongst myriad actors to ensure that a biofuel is "sustainable" from the time the feedstock is produced in the fields to the time it reaches the consumer in the EU market. This form of regulation is also known as "meta-standard regulation" whereby "[i]nstead of requiring producers to be certified to the Meta-Standard [i.e., the RED sustainability criteria in this case] directly, compliance with the Meta-Standard can be achieved through certification to existing standards which have proven to provide a sufficient guarantee that (most of) the...criteria of the Meta-Standard are complied with". ${ }^{53}$

\section{The State as Orchestrator}

Building on Abbott and Snidal's ideas about the emergence of "Transnational New Governance", the following discussion will examine how this unique compliance framework is an example of how the EU is proactively employing New Governance techniques at the transnational level to achieve desired regulatory goals. Abbott and Snidal acknowledge that the "mapping" of Old Governance from the domestic level onto the international level is not without difficulties, mainly because the international system does not have a hierarchically superior "state" that has the authority to adopt mandatory regulations or to impose sanctions. ${ }^{54}$ However, Old Governance at the domestic and international levels shares similar characteristics. At the domestic level, Old

\footnotetext{
${ }^{52}$ M. Hatanaka \& L. Busch, "Third-party certification in the global agrifood system: an objective or socially mediated governance mechanism?" (2008) 48 Sociologia Ruralis 73-91. For an interesting and enlightening discussion about the role of auditors in verifying compliance with land governance criteria in two biofuels certification schemes, Bonsucro (formerly the Better Sugarcane Initiative) and the Roundtable on Sustainable Biofuels, see E. Fortin a \& B. Richardson, "Certification Schemes and the Governance of Land: Enforcing Standards or Enabling Scrutiny?" (2013) 10(1) Globalizations 141-159, pages 147-8, 151-2.

${ }^{53}$ Dehue et al, "Towards a Harmonised Sustainable Biomass Certification Scheme", Ecofys 2007, online: www.assets.panda.org (accessed on 1 March 2013), page 4.

${ }^{54}$ K.W. Abbott \& D. Snidal, "Strengthening International Regulation through Transnational New Governance: Overcoming the Orchestration Deficit" (2009) 42 Vanderbilt Journal of Transnational Law 501- 578, page 534. [Abbott \& Snidal]
} 
Governance refers to the state governing regulated activities via "command and control" and the main enforcement mechanism consists of coercive sanctions. Old Governance relies on "hard law". The Old Governance view of societal actors is that they are selfinterested and unaccountable, and therefore incapable of self-regulation or playing any meaningful role in state regulation. ${ }^{55}$ At the international level, Old Governance comprises of treaty law ("hard law") and an array of issue-specific inter-governmental organisations (IGOs) which are created and governed by their member states. Albeit to a lesser degree compared to the domestic level, international Old Governance also comprises of centralized governance (by the IGOs) whose legitimacy is based on formal authority and bureaucratic expertise. ${ }^{56}$

The New Governance model of regulation is difficult to define precisely but it can be understood to refer to a diverse range of innovative regulatory practices that stand in contradistinction to Old Governance. ${ }^{57}$ The salient distinction between Old Governance and New Governance is the differing role that the state plays in regulation; all other characteristics flow from this primary distinction. The weakness of the state is often seen to be the main reason for the rise of domestic New Governance. ${ }^{58}$ New Governance incorporates a decentralized range of public and private institutions and actors into the regulatory system by, for example, encouraging self-regulation by industry, relies on this range of actors for regulatory expertise, and makes use of "soft law" (for example, codes of conduct) to complement or substitute mandatory "hard law". ${ }^{59}$ In New Governance, the state remains a significant actor but it behaves less as a "commander" and more as an "orchestrator" that facilitates and directs collaborative

\footnotetext{
${ }^{55}$ John Braithwaite, "Responsive Regulation and Developing Economies" (2006) 34 World Development 884, page 886-887.

${ }^{56}$ Abbott and Snidal, page 534.

${ }^{57}$ Since Lester Salamon "The New Governance and the Tools of Public Action" (2001) 28 Fordham Urban Law Review 1611-1674, the seminal work that introduced New Governance as "the silent revolution", there has been a proliferation of scholarship on New Governance. See, for example, Grainne de Burca \& Joanne Scott (eds.), Law and New Governance in the EU and the US (Hart Publishing: 2006); Orly Lobel, "The Renew Deal: The Fall of Regulation and the Rise of Governance in Contemporary Legal Thought" (2004) 89 Minnesota Law Review 342.

${ }^{58}$ Grainne de Burca \& Joanne Scott, "Narrowing the Gap: Law and New Approaches to Governance in the European Union" (2007) 13(3) Columbia Journal of European Law 513, pages 513-4. [de Burca \& Scott]

59 Jeroen van der Heijden, "Looking Forward and Sideways: Trajectories of New Governance Theory", Amsterdam Law School Legal Studies Research Paper No. 2013-04, pages 4-6; online:

http://papers.ssrn.com/sol3/papers.cfm?abstract id=2204524 (accessed on 19 April 2013).
} 
regulation by the network of actors. ${ }^{60}$ The state often initiates New Governance programmes as it recognises New Governance as an important regulatory tool and uses it proactively. ${ }^{61}$ Therefore, behind all New Governance programmes lurks the hand of the state. For example, the state can require private actors and institutions to abide by due process norms/ administrative law and can retain the threat of introducing mandatory regulation should self-regulation prove to be unsatisfactory. ${ }^{62}$

Abbott and Snidal argue that the expanding array of private, public-private and IGO initiatives such as eco-labelling schemes, the United Nations Global Compact and the chemical sector's "Responsible Care" self-regulation programme (which they refer to as forms of "regulatory standard-setting")"'is developing into a system of Transnational New Governance for business. As in the New Governance model, these schemes form "a decentralized but increasingly dense and interlinked constellation of private and public-private arrangements....which surrounds and complements traditional state-based regulatory structures". ${ }^{63}$ Dingwerth has suggested that in the absence of a "zone of agreement" amongst states to conclude MEAs, these private and hybrid public-private rule-making processes have entered to fill the gap as a result of the failure of public rule-making. ${ }^{64}$ Using different terminology, Cashore conceptualizes the expanding array of private governance initiatives as "non-state-market-driven (NSMD) governance". ${ }^{65}$ NSMD governance systems such as forest certification derive their authority not from the state but from the manipulation of global market forces and consumer preferences. The state does not exercise its sovereign authority to require compliance with the rules generated by NSMD governance processes, although it can seek to influence and shape NSMD rules like any other interest group. ${ }^{66}$ It can be argued that the EU biofuels scheme is an example of NSMD governance whereby the state is acting in ways

\footnotetext{
${ }^{60}$ Abbott and Snidal, page 521.

${ }^{61}$ Ibid, page 523.

${ }^{62}$ Ian Ayres and John Braithwaite, Responsive Regulation: Transcending the Deregulation Debate (Oxford University Press, 1992), page 158.

${ }^{63}$ Abbott and Snidal, pages 509-510.

${ }^{64}$ K. Dingwerth, "The Democratic Legitimacy of Public-Private Rule Making: What Can We Learn from the World Commission on Dams?" (2005) 11 Global Governance 65-83, page 71.

${ }^{65}$ B. Cashore, "Legitimacy and the privatization of environmental governance: How non-state market-driven (NSMD) governance systems gain rule-making authority" (2002) 15(4) Governance 503-529.

${ }^{66} \mathrm{lbid}$, page 510.
} 
consistent with NSMD governance such as implementing policies that create market demand for certified biofuels, but not using its sovereign authority to require adherence with the sustainability criteria. Business actors will seek certification because they wish to access the EU market, not because certification is required by law.

Abbott and Snidal advance the normative argument that states and IGOs ought to promote Transnational New Governance to fill the gaps of international Old Governance. However, Transnational New Governance will take off only if states and IGOs provide the necessary "orchestration and support". 67 "Orchestration includes a wide range of directive and facilitative measures designed to convene, empower, support, and steer, public and private actors engaged in regulatory activities" ${ }^{68}$ They point out that the greatest current weakness of Transnational New Governance is the lack of orchestration. ${ }^{69}$ As the above description of the EU "sustainable biofuels" compliance framework shows, the EU (the "state") can be said to be engaging in "directive orchestration". ${ }^{70}$ It is imposing conditions on public benefits and giving state endorsement to "approved" schemes to bolster the practice of biofuels eco-labelling. By the meta-standard approach, the EU is also performing an important facilitative role of encouraging uniformity of standards across competing biofuels certification schemes. This reduces excessive multiplicity which encourages "forum-shopping" amongst biofuels producers and causes confusion on the part of consumers. ${ }^{71}$

To point out the obvious, the EU's resort to Transnational New Governance allows it to hedge against some of the legal uncertainties (concerning WTO compliance) associated with linking social and environmental standards to trade. ${ }^{72}$ Further, the Commission can hardly claim to have the ability or the resources to police compliance

\footnotetext{
${ }^{67}$ Abbott and Snidal, pages 509-510.

${ }^{68}$ Ibid.

${ }^{69}$ Abbott and Snidal, page 545.

${ }^{70} \mathrm{lbid}$, page 544

${ }^{71}$ See discussion in Jody M. Endres, "Clearing the Air: the Meta-standard approach to ensuring biofuels environmental and social sustainability" 28(2010) Virginia Environmental Law Journal, pages 108-111.

${ }^{72}$ For discussion, see, for example, Steve Charnovitz, Jane Earley and Robert Howse, An Examination of Social Standards in Biofuels Sustainability Criteria (International Food \& Agricultural Trade Policy Council Discussion Paper - Standards Series, December 2008), online: http://www.agritrade.org/documents/SocialStnds Biofuels FINAL.pdf (accessed on 19 April 2013).
} 
with the RED sustainability criteria in plantations and production plants outside the EU. Going back to the concept of TEL, the above discussion shows how the limitations of traditional IEL/international Old Governance can be overcome (to a certain extent) by resort to transnational regulation. As Krasner has argued, transnational private regulation can help governments to escape certain constraints. ${ }^{73}$ TEL embodies a broad understanding of law (in the pluralist sense) and regulation, and includes regulatory innovation of the kind commonly associated with New Governance. Most scholars of the New Governance school favour a hybrid of Old Governance and New Governance, in which the state maintains a baseline of minimum mandatory regulation, regulates those actors which do not subscribe to New Governance, and uses New Governance to implement or supplement mandatory law. ${ }^{74}$ This is an acknowledgment of the significant role that the state continues to play in regulating even though it is no longer the sole locus of authority. Similarly, while TEL recognises the role of the community, private individuals and the market in global environmental governance, it by no means discounts the import of the state.

\section{Legitimacy}

Inevitably, questions of the legitimacy of TEL are raised. In the context of the EU sustainable biofuels regime, two broad questions concerning legitimacy arise. The first question concerns the legitimacy of the EU using market access as a policy mechanism to unilaterally impose environmental standards on their trading partners. The other question concerns the legitimacy of rule-making, rule promotion and adjudication of compliance by private authorities (i.e, the certification schemes and auditors). ${ }^{75}$ Both

\footnotetext{
${ }^{73}$ S. D. Krasner, "Power politics, institutions, transnational relations" in T. Risse-Kappen, Bringing Transnational Relations Back In: Non-State Actors, Domestic Structures and International Institutions (Cambridge: Cambridge University Press, 1995).

${ }^{74}$ De Burca \& Scott, pages 514-5; David M. Trubek and Louise G. Trubek, “New Governance and Legal Regulation: Complementarity, Rivalry, and Transformation" (2007) 13 Columbia Journal of Environmental Law 539, pages 5412.

${ }^{75}$ For example, Chimni has argued that the worrisome aspect of "global law without a state" is the absence of transparency. Further, "the deterritorialized legal order takes advantage of its well-honed internal practices to subvert state legal orders, in particular in third world countries....global law without the state [also] often does not take into account the socio-economic context in third world countries"; B.S. Chimni, "International Institutions Today: An Imperial Global State in the Making" (2004) 15(1) European Journal of International Law 1-37, page 18.
} 
types of legitimacy concerns have prompted calls for a "multilateral governance framework" for biofuels, the institutional design of which seeks to promote public participation, transparency and deliberative decision-making. ${ }^{76}$ Lima, for example, argues that sustainability regulation in the form of voluntary certification schemes and the EU sustainability criteria lack transparency and are "...a weak replacement for a structured multilateral legal framework as demanded by the principle of the rule of law". ${ }^{77}$ Both sets of legitimacy concerns will be addressed in turn below.

States are not globally representative; their governments can only speak for the common interests of the electorate that put them into power. ${ }^{78}$ Given the policy differences between developed countries and developing ones, the legitimacy of developed countries unilaterally directing international policy is questionable. ${ }^{79}$ It can be argued that the EU's unilateral imposition of environmental standards on other members of the international community raises questions of political legitimacy, that is, the acceptance and justification of shared rule by a community. ${ }^{80}$ In this regard, legitimacy is "the justification of actions to those whom they affect according to reasons they can accept". ${ }^{81}$ Justification of authority is, in turn, deemed essential to securing compliance or the obedience of the governed. However, this argument could well be set aside as erroneously based on a misconception of what the EU is trying to achieve through unilateral action. Scott has argued that the ultimate goal of the EU's resort to traderelated environmental measures "is not to enforce compliance with EU rules on the part of operators situated abroad, but it is on the contrary to galvanise or incentivise

\footnotetext{
${ }^{76}$ Mairon G. Bastos Lima, “Biofuel Governance and International Legal Principles: Is it Equitable and Sustainable?” (2009) 10(2) Melbourne Journal of International Law 470-492.

${ }_{77}$ Ibid, page 492.

${ }^{78}$ That a state is acting to promote community rather than national interests arguably ameliorates such concerns about the lack of legitimacy; see Gregory Shaffer \& Daniel Bodansky, "Transnationalism, Unilateralism, and International Law" (2012) 1(1) Transnational Environmental Law 31-41, page 38. [Shaffer \& Bodansky]

${ }^{79}$ Cultural imperialism, in that developed countries might impose inappropriate standards and cultural values on developing countries, is another salient concern.

80 S. Bernstein, "Legitimacy in Global Environmental Governance" (2005) 1(1-2) Journal of International Law and International Relations 139-66. [Bernstein, 2005]

${ }^{81} \mathrm{M}$. Williams, "Citizenship as Agency within Communities of Shared Fate" in S. Bernstein and W.D. Coleman (eds) Unsettled Legitimacy: Political Community, Power, and Authority in a Global Era (Vancouver: University of British Columbia Press, 2009) 33-52, page 43.
} 
regulatory or normative engagement elsewhere" ${ }^{82}$ This idea of using market access to influence the regulatory policies of trading partners is not new. Vogel's Trading Up, published in 1995, is the seminal work on the concept of 'the lure of green markets'. ${ }^{83}$ Vogel demonstrated how more stringent regulation in a large market led large companies to adapt to that regulation, providing them with a comparative advantage and creating incentives for these companies to lobby for more stringent regulation in other jurisdictions that have yet to do so. The result is what Vogel termed the "California effect" - the dissemination of stricter environmental regulation across borders. Vogel thereby also demonstrated that unilateral regulatory action by a state exercising market power creates TEL (i.e., the creation and diffusion of norms across borders).

Bernstein has demonstrated that what counts as a legitimate institution varies across inter-governmental and non-state institutions. ${ }^{84}$ His research has shown that despite trenchant criticism of the Kyoto Protocol, the United Nations Framework Convention on Climate Change framework continues to be seen as the legitimate forum for climate change governance. At the same time, non-state based forms of governance are held up to far more stringent requirements of accountability and transparency in order to be considered legitimate. A major reason for this difference in attitudes towards state-based and non-state based governance structures is that the Kyoto Protocol adheres to what legitimacy demands of a MEA - state consent. ${ }^{85}$ In short, a treaty that is the product of agreement amongst equal sovereigns enjoys legitimacy and is therefore the ideal type. However, in comparing TEL (based on unilateral action) with IEL (based on multilateral negotiations), the comparison is not between an imperfect institution and a perfect ideal. The comparison is one between two imperfect institutional alternatives. To foster legitimacy, multilateral negotiations require agreement by consensus. This permits a single state or a small group of states, especially when there are free-rider or collective action issues at stake, to stall negotiations and delay action

\footnotetext{
82 Joanne Scott, "The Multi-Level Governance of Climate Change" (2011) 1 Carbon and Climate Law Review 25-33.

${ }^{83}$ Vogel, Trading Up: Consumer and Environmental Regulation in a Global Economy (Harvard University Press, 1995), page 261.

${ }^{84}$ S. Bernstein, "Legitimacy in intergovernmental and non-state global governance" (2011) 18(1) Review of international political economy 17-51.

${ }^{85}$ Ibid, page 31.
} 
by the international community. Unilateral action that is applied in a principled manner (e.g., in a non-discriminatory manner and subject to due process constraints) may be an imperfect but superior alternative to the complete lack of action to promote environmental interests. ${ }^{86}$ In the biofuels context, multilateral negotiations for a regulatory framework have not begun, arguably due to the international community's lack of enthusiasm for this approach in light of the long-standing stalemate in international climate change treaty negotiations. In this climate of treaty fatigue, TEL offers some states (inevitably the economically powerful ones like the EU and the US which can leverage on their economic might) a pathway for advancing environmental interests.

It can further be argued that the idea of outright imposition of rules by one actor on another (which rightly gives rise to legitimacy concerns) is too simplistic. First, while recognizing the vulnerability of export-driven economies to the demands of economically powerful markets such as the EU, the former are not entirely powerless and defenceless actors who have no choice but to submit in acquiescence to a bully. To reiterate the earlier point made by Scott, the use of market access to shape transnational environmental policy is to tap into the logic of free markets and rational behaviour to create incentives for regulatory action outside the EU when no incentives existed before.

Let us take the Indonesian Sustainable Palm Oil Scheme (ISPO) as a case in point. In 2010, the Indonesian government announced that they will be developing a nationwide mandatory certification scheme for the palm oil sector. ${ }^{87}$ The government gave two official reasons for this policy decision. ${ }^{88}$ First, the conditions imposed by the EU sustainability criteria and related to this, the need for Indonesian palm oil to remain

\footnotetext{
${ }^{86}$ For discussion of the critical role that international law plays in disciplining unilateral action as part of the broader TEL process, see Shaffer \& Bodansky, pages 39-41.

${ }^{87}$ As it is a nationwide scheme, it will include the small-scale, palm oil growers who produce on a subsistence-like basis but contribute $40 \%$ of Indonesia's total output (Interview No. 2 with sustainability manager of major biofuel producer firm, on file with author).

${ }^{88}$ Rosediana Suharto, "Why Indonesia needs ISPO", The Jakarta Post, 12 February 2010, online: http://www.thejakartapost.com/news/2010/12/02/why-indonesia-needs-ispo.html (accessed on 9 February 2013). [Suharto]
} 
competitive in the global commodity markets. By 2010, palm oil had gained a notorious international reputation. Transnational environmental activist groups like Greenpeace had conducted highly visible public campaigns against multinational companies whose well-known consumer products contain palm oil to raise awareness of the damage done to Indonesian tropical rainforests by industrial palm oil production (Deforestation in Indonesia for palm oil and illegal logging is so rapid that it has been estimated that the country's forests might be destroyed by 2022)..$^{89} 90$ These campaigns succeeded in pressuring some global brands to commit towards using only certified (sustainable) palm oil in their products and to suspend purchases from Indonesian producers which allegedly clear primary forests or peatland to set up palm oil plantations. ${ }^{91}$ The Indonesian government recognized the Indonesian palm oil sector would lose its competitive advantage if it continued "business as usual" and ignored these issues. ${ }^{92}$

Critics may point out that, given the prominence of the Roundtable on Sustainable Palm Oil (RSPO) certification scheme, it is curious that the Indonesian government elected to develop a new standard rather than promote RSPO certification. ${ }^{93}$ These

\footnotetext{
${ }^{89}$ Nellemann, C., Miles, L., Kaltenborn, B. P., Virtue, M., and Ahlenius, H. (eds), "The last stand of the Orangutan 'State of emergency: Illegal logging, fire and palm oil in Indonesia's national parks, (2007) United Nations Environment Programme, GRID-Arendal (Norway), available online: http://www.unep.org/grasp/docs/2007JanLastStand-of-Orangutan-report.pdf (accessed on 10 March 2011).

${ }^{90}$ See, for example, the highly visible campaign launched by Greenpeace, "Ask Nestle to Give Rainforests a Break", which led to Nestle announcing a new policy committed towards identifying and excluding companies in its supply chain that owe or manage plantations linked to deforestation, such as certain palm oil producers/processors; online: http://www.greenpeace.org/international/en/news/features/Sweet-success-for-Kit-Kat-campaign/ (accessed on 10 March 2013).

91 "Indonesia develops rival sustainable palm oil scheme", The Jakarta Post, 11 October 2010, online: http://www.thejakartapost.com/news/2010/11/10/indonesia-develops-rival-sustainable-palm-oil-scheme.html (accessed on 9 February 2013).

92 The Netherlands, Italy, Germany and Spain are the four EU Member States that are amongst the top ten major destination countries for Indonesian crude palm oil, accounting for about $23 \%$ of total annual export (measured in tonnes) in 2008, 2009 and the first six months of 2010. India is the single largest importer of Indonesian crude palm oil. Exports to India accounted for $46 \%$ of the total exports between 2006 and June 2010. TradeData International Analysis Report, An Analysis of Indonesian Exports of Crude Palm Oil, 14 October 2010, available online: http://tradedata.net/files/1TQQ3XTKTI/Indonesian exports of Crude Palm Oil HS Code 1511100000 .pdf (accessed on 29 March 2013).

${ }^{93}$ Ponte and Cheyns describe the RSPO as "...the most important and visible sustainability network in the palm oil industry"; see S. Ponte \& E. Cheyns, "Voluntary Standards, Expert Knowledge and the Governance of Sustainabilty Networks" (forthcoming in Global Networks, on file with author), page 13. [Ponte and Cheyns]
} 
critics are likely to dismiss the ISPO as a state-backed effort to evade the more rigorous requirements for RSPO certification. However, there may be validity to the Indonesian government's claim that RSPO certification is expensive and requires extensive documentation. ${ }^{94}$ It is out of reach for the thousands of illiterate small-scale farmers who sell their small output to the processing mills. Out of about 2000 plantations in Indonesia, less than 50 were certified by the RSPO in 2010. There was therefore real concern about whether Indonesia could produce enough certified palm oil.

Whether certification by the RSPO or the ISPO is effective in enforcing standards or merely enables scrutiny is a valid question for more empirical study. For present purposes, the point that this article seeks to make is that the Indonesian government would not have introduced the ISPO if not for the transnational regulatory pressure by transnational civil society and the EU biofuels scheme. The ISPO is not a response of weakness, of caving in to EU pressure. The ISPO is domestic regulation that, for all its flaws and weaknesses due to endemic problems of corruption and lax enforcement within the archipelago of a thousand islands, is created by a state (Indonesia) and tailored to meet its domestic circumstances. There is interaction between transnational norms and domestic factors that led to regulatory change in Indonesia. That is the essence of TEL. To argue that unilateralism is essentially economic bullying misses this subtle aspect of the regulatory dance that TEL sets in motion.

Scharpf has posited two main forms of legitimacy: input (process) and output (performance and effectiveness) legitimacy. From the viewpoint of output legitimacy, to the extent that a particular set of rules or standards promotes the common good, it should be seen to be legitimate; the process leading to the promulgation of a norm is

\footnotetext{
For more discussion of the RSPO, also see E. Cheyns, "Multi-stakeholder Initiatives for Sustainable Agriculture: The Limits of the 'Inclusivenes' Paradigm" in S. Ponte, P. Gibbon and J. Vestergaard (eds.), Governing through standards: origins, drivers and limits (London: Palgrave, 2011) 210-35; W.F. Laurance et al. "Improving the performance of the Roundtable on Sustainable Palm Oil for nature conservation." (2010) 24(2) Conservation Biology 377-381; J.F. McCarthy, P. Gillespie, and Z. Zen, "Swimming upstream: Local Indonesian production networks in "globalized" palm oil production" (2012) 40(3) World Development 555-569; G. Schouten and P. Glasbergen, "Creating legitimacy in global private governance: The case of the Roundtable on Sustainable Palm Oil", (2011) 70(11) Ecological economics 1891-1899.

${ }^{94}$ Suharto.
} 
not pertinent to its legitimacy, and democracy has no role to play in fostering legitimacy. As Perez points out, under this account, "the question is rather which set of criteria constitutes the best expression of the common good". ${ }^{95}$ The role of experts in determining these standards (and defining what "the common good" constitutes) and how private governance schemes build legitimacy through expertise has been the focus of numerous studies about standards in the literature. Jacobsson argues that standardsetting organizations build legitimacy through presenting their standards as "expert knowledge stored in the form of rules" ${ }^{96}$ Kerwer posits that a necessary (but not always sufficient) precondition for the effectiveness of standards is that the target audience(s) believe that the expertise on which the standards are based is convincing. ${ }^{97}$

However, with declining trust in experts and their professed expertise, the power of "...expert knowledge to provide privileged accounts of the common good and, hence, to serve as a source and arbiter of legitimacy" has also declined. ${ }^{98}$ Instead, the conception of legitimacy that is gaining ascendency in contemporary global society is one that places emphasis on the process that leads to the production of a transnational norm, that is, input legitimacy. "[T]he legitimacy of transnational regimes is judged, increasingly, by the nature of the process that led to the regimes' creation, and by the public accountability of those who implement them". "A9 "As such, democratisation" is often viewed as the solution to the "legitimacy problem". ${ }^{100}$ Held has observed that "[d]emocracy seems to have scored a historic victory over alternative forms of governance...[It] bestows an aura of legitimacy on modern political life: laws, rules and

\footnotetext{
${ }^{95}$ Oren Perez, "Normative Creativity and Global Legal Pluralism: Reflections on the Democratic Critique of Transnational Law" (2003) 10(2) Indiana Journal of Global Legal Studies 25-64, page 28. [Perez]

${ }^{96}$ B. Jacobsson, "Standardization and expert knowledge" in N. Brunsson and B. Jacobsson (eds) A World of Standards (Oxford:Oxford University Press, 2000): 40-49, page 41;

97 D. Kerwer, "Rules that many use: standards and global regulation" (2005) 18(4) Governance 611-632, page 618; Also see T.A. Loya and John Boli, "Standardization in the World Polity: Technical Rationality over Power" in John Boli and George M. Thomas (eds.), Constructing World Culture: International Nongovernmental Organizations since 1875 (Stanford: Stanford University Press, 1999).

${ }^{98}$ Perez, page 28.

${ }^{99}$ Perez, page 29.

${ }^{100}$ See, for example, D. Bodansky, "The Legitimacy of International Governance: A Coming Challenge for International Environmental Law" (1999) 93(3) American Journal of International Law 596-624; A. Buchanan and R. O. Keohane, "The legitimacy of global governance institutions" (2006) 20(4) Ethics \& International Affairs 405-437; T. Risse, "Transnational governance and legitimacy" in A. Benz and I. Papadopoulos (eds) Governance and Democracy: Comparing national, European and international experiences (London: Routledge, 2012) 179-199.
} 
policies appear justified when they are 'democratic'”. 101

Yet, the meaning of the concept of "democracy" in the transnational arena is highly contested. There is no consensus on what constitutes adequate participation and deliberation for a regulatory system to be deemed "democratic" and hence "legitimate". 102 Bernstein's analytical framework highlights that a checklist of legitimacy requirements cannot be developed a priori because the concept of legitimacy is a shifting one, one that evolves over time and is also highly contingent on the interactions of power within social structures of affected communities. ${ }^{103}$ What many private authority schemes have sought to do is to include transparency and accountability mechanisms in their governance structures and rule making processes to further representative and deliberative democracy and thereby increase their input legitimacy. Meidinger suggests that this is a form of anticipatory democracy at work as these regulatory programmes aim to anticipate emergent public values, institute mechanisms to advance them and thereby enhance authority. ${ }^{104}$ The Forestry Stewardship Council (FSC) is often held up as the 'poster child' of treating transparency and stakeholder consultation as ends unto themselves. ${ }^{105}$ However, there is a "legitimacy trade off" which private authority schemes have to grapple with: high levels of participation and transparency increase support and buy-in, but also slow down decision-making processes and potentially impede timely action on policy problems. ${ }^{106}$ Auld and Gulbrandsen's comparative study of the FSC and the Marine Stewardship Council shed light on how schemes may choose to design their institutional features differently to

\footnotetext{
${ }^{101}$ D. Held, Democracy and the global order: From the modern state to cosmopolitan governance (Stanford: Stanford University Press, 1995), page 3.

${ }^{102}$ Also see discussion in S. Bernstein, "Legitimacy in intergovernmental and non-state global governance" (2011) 18(1) Review of international political economy 17-51, pages 21-23 on the assumed relationship between democracy and legitimacy in global governance.

103 Ibid, page 42.

${ }^{104}$ E. Meidinger, "Competitive supragovernmental regulation: how could it be democratic" (2007) 8(2) Chicago Journal of International Law 513-534, pages 531-2. [Meidinger]

${ }^{105}$ G. Auld and L. H. Gulbrandsen "Transparency in nonstate certification: consequences for accountability and legitimacy" (2010) 10(3) Global Environmental Politics 10.3 97-119. [Auld and Gulbrandsen]

For an excellent discussion of the FSC, see Steven Bernstein and Benjamin Cashore, "Nonstate Global Governance: Is Forest Certification a Legitimate Alternative to a Global Forest Convention?" in John Kirton and Michael J. Trebilcock (eds), Hard Choices, Soft Law: Voluntary Standards In Global Trade, Environment And Social Governance (Ashgate Publishing, 2004).

${ }^{106}$ Bernstein, 2005.
} 
address this trade-off. ${ }^{107}$

Abbott and Snidal argue that these are "[p]ragmatic steps [that] constitute sensible approaches to developing democracy in an arena where the very meaning of the concept is in doubt; over time, they could have significant consequences for global democracy". ${ }^{108}$ However, the jury is still out on this issue as more empirical evidence of how participation actually works in private regulatory schemes is needed. ${ }^{109}$ One indication, by Ponte and Cheyns, is that "sustaintability networks are far less inclusive, transparent and participatory than they portray themselves to be" as they manipulate who gets to participate and use subtle techniques to drown the voices of politically weaker actors. ${ }^{110}$ This article argues that the democratization of TEL, for example, through the creation of inclusive models of deliberation and public participation is a laudable objective in pursuit of the genuine aspiration to subject transnational issues to deliberation by all who are affected. However, this is a "work-in-progress" in pursuit of a moving target (that is, the shifting and contested notion of democracy in the transnational context). It is premature to conclude that TEL is illegitimate on this ground. It is an imperfect institutional design but has the potential to fill the gaps and inadequacies of traditional IEL.

\section{Part IV: Conclusion}

This article sought to outline the contours of the emerging concept of TEL. Part II of this article was devoted to providing a broad overview of the salient aspects of transnational law and how these aspects are carried over to TEL. In addition, this article advanced the argument that traditional IEL provides too narrow a set of ideas and concepts for environmental law scholars to engage effectively with contemporary environmental issues. Scholars who have sought to go beyond the state-centric foci of IEL have tended to draw from other disciplines like geography, political science and

\footnotetext{
${ }^{107}$ Auld and Gulbrandsen.

${ }^{108}$ Abbott and Snidal, page 555.

${ }^{109}$ Meidinger, page 533, makes the same point.

${ }^{110}$ Ponte and Cheyns, page 19.
} 
anthropology. These endeavours have enriched and advanced the frontiers of environmental law scholarship. TEL offers another promising avenue for scholars seeking to venture beyond state-centred ideas of law to capture the realities of contemporary global social ordering.

Using the EU sustainable biofuels regime as a case study, this article showed how the EU is creating TEL by using market access to incentivise regulatory action abroad and by applying New Governance techniques at the transnational level. These courses of action are not without criticism, particularly of the legitimacy of trade-related unilateral action to advance environmental interests and the legitimacy of private regulation. While recognising the validity of these legitimacy concerns, this article argued for a more nuanced understanding of trade-related environmental measures. It was also argued that private regulation is by no means perfect, but the attempts made by roundtable certification schemes to promote inclusive and transparent decisionmaking are laudable. An interim conclusion would be that it is too premature to strike TEL down on legitimacy grounds.

Biofuels poses significant governance challenges because of its numerous interfaces with pressing policy issues such as rural poverty, food security, agricultural policy and global finance. For an observer, what has been striking is the speed at which the policy discourse has shifted from unequivocal championing of biofuels as a silver bullet to one that weaves far more narratives that shed light on the social and environmental damage that can be caused by industrial biofuels production. These narratives bring to attention the plight of the oppressed, the marginalised, and the forgotten. The speed of this shift in discourse and consequent international policy is, in large part, due to transnational forces. Through the lenses of TEL, scholars may find a useful "vocabulary" to consider such developments and contribute towards developing fair and just solutions to global environmental challenges. 